\title{
10. The NSW Steam Trawl Fishery on the South-East Continental Shelf of Australia, 1915- 1961
}

\begin{abstract}
Anne Lif Lund Jacobsen
Today commercial fishing in New South Wales (NSW), Australia, is one of the state's important food producing industries. It is estimated that landings of wild harvested fish from NSW's waters have an annual value of \$94 million, of which ocean catches (by hauling, trap, line or trawl) comprised around half. ${ }^{1}$ The earliest known ocean fishing grounds were located on the continental shelf at a depth of 200 metres or less in waters mostly south of Sydney, but over time fishing spread out to also cover grounds in Bass Strait. Today the fishery includes several states, covering fishing grounds along New South Wales, Victoria, around Tasmania and South Australia, known as the Commonwealth Trawl Sector (previously the South East Trawl Fishery), and is managed by the Commonwealth under a single management plan with the exception of some inshore areas which are still managed by the relevant States.

However fishing, and especially on the open sea, has not always played a role in the NSW's economy. When looking up 'Fisheries' in the official government year book of New South Wales between 1888 and 1901 one would find this entry:
\end{abstract}

The seas that wash the shores of New South Wales abound with fish, but this source of wealth to the State has been greatly neglected (Statistician's Office, The Wealth and

Progress of New South Wales 1887-1902).

The entry reflected a heated debate in NSW, fought in newspapers and in parliament, over why the State did not utilize the sea and its marine resources to develop a larger fishing industry. By 1888 the Australian sea fishing industry was mainly small and inshore-based and there had been no attempt to commercially exploit the species found on the continental shelf. Towards the end of the nineteenth century, as a pro-fisheries development position gained support, significant political pressure emerged for the State to support industry development. Although none had investigated the extent to which marine resources were available on the southeast continental shelf, it was taken for granted that rich fishing grounds existed and that they were suitable for large-scale commercial harvesting.

In 1914, an opportunity to develop offshore fisheries arose when high prices for meat made it attractive for the sitting Labor Government to expand its program of state-driven businesses to include a new fishing enterprise (Tyler 2006). This type of public development policy, with direct industry intervention, is known as 'colonial socialism' and has played a key role in Australia's economic development (Butlin et al. 1982). 


\section{The NSW State Trawling Industry - the beginning of trawling in Australia, 1915-1923}

Australia's first demersal trawl fishing industry was established in June 1915 under the name of the 'NSW State Trawling Industry' (STI), when the NSW government founded an offshore, large-scale fishing industry, modelled on the British trawling industry in the North Atlantic. The aim of the government was to provide consumers, primarily in Sydney, with trawled fish. During 1909-14 promising trawling grounds on the continental shelf had been identified by the Australian Commonwealth research vessel Endeavour. The NSW Government established the industry by investing in a fleet of three modern British built steam trawlers. The plan was to run the trawling industry on a commercial basis, and at the same time provide consumers with cheap trawled fish through a network of state-owned fish-shops located in the main population areas.

Initially the scheme was a success and during the next years six more vessels were built at the State Dockyard in Newcastle. To store catches central depots with large cold storage facilities was erected on No. 5 Wharf, Woolloomooloo Bay, Sydney, and in Newcastle. In order to distribute catches, an extensive network of fish shops serviced by lorries was established. In addition a network of coastal receiving stations (coastal depots), serviced by a transport vessel were initiated to boost local fishing communities. By 1923 trawled fish was responsible for 1,302 tons or $14 \%$ of the state's total fish landings (Jacobsen 2010). The species target was mainly tiger flathead (Neoplatycephalus richardsoni), but latchet (Pterygotriglia polyommata), chinaman leatherjacket (Nelusetta ayraudi), jackass morwong (Nemadactylus macropterus) and redfish (Centroberyx affinis) was also landed. In the beginning the species found on the trawling grounds were little known by the consumers but, as state trawled fish was sold below the price of privately caught fish from inshore waters, a market for these new species quickly developed.

However, the dual purpose of the STI, to develop a new fishing industry as well as provide cheap fish for NSW's urban populations on a commercial basis, made the STI rigid and expensive to run. As the ambition of the state-owned trawling industry increased after 1915, expenses spiralled out of control. As a result by 1922 there was no longer political support for the scheme, and it was decided to sell the industry.

\section{The rise of private steam trawling}

In February 1923 the STI's assets was announced for sale. In the sales advertisement it was specified that preference would be given to applicants planning to continue the industry, ${ }^{2}$ as the Government was still keen to continue nurturing the 
development of an offshore fishing industry. During the next half-year all the company's seven trawlers, ${ }^{3}$ as well as the Industry's buildings, gear and other assets were sold.

Despite the Government's obvious efforts to liquidate the STI as quickly as possible, buyers were not queuing up. No offers were received for the entire industry; and of the vessels, only the three British built trawlers initially attracted any interested buyers. Of all vessels only the British build Koraaga, bought by the locally based, newly formed Coastal Trawling Company, ${ }^{4}$ was sold to a price similar to the vessels launch-cost; the costs associated with outfitting and delivery to Sydney was never recovered. ${ }^{5}$ The two remaining British built trawlers were sold for $£ 4,400$ and $£ 3,400$ respectively to New Zealand based Sanford Ltd, the largest fishing company in Auckland, where almost half of the New Zealand catches were landed. For about a year Sanford trawled the south east continental shelf before they sold the trawlers back to a Sydney company in 1925 because of low returns.

In hindsight the interlude with the New Zealand fishing company was symptomatic of some fundamental problems surrounding the trawl fishery on the south east continental shelf. As Sanford Ltd. was already a well-established trawling company in New Zealand it was in a position to realistically assess the situation of the fishery. Wanting to expand its business to Australia Sanford Ltd. had opened a depot in Sydney to handle the New Zealand imported fish as well as local species caught by its steam trawlers. ${ }^{6}$ In 1925, as Sanford realised that 'while the distribution business [in NSW] was satisfactory, trawling was not' (Johnson 2004), the trawlers were sold off. What Sanford had grasped was that the productivity of the shelf was relatively low, especially compared to the New Zealand grounds. With an ample supply of New Zealand trawled fish, Sanford could eliminate the costly steam trawling operations for local species and concentrate on selling New Zealand caught fish which was in much more ample supply.

After the STI's British built trawlers were sold, the four vessels built at the NSW government's own dockyard were slowly sold during the second half of 1923. As an example the first NSW build trawler to be sold was Goonambee, which was handed over to a short-lived local syndicate called Tucabia Fisheries Ltd. for $£ 3,500$ on twelve months terms. When the STI had Goonambee delivered from the Government dockyard in May 1917 the total costs of delivery had been $£ 23,725$. As the rest of the vessels were sold at similar prices the Government's total write-off was substantial. As trawl fishing proved commercially viable under private management, the remaining vessels sold at slightly higher prices.

While it had taken about half a year for the NSW Government to sell all the vessels, the shops and other leases were more easily disposed of, although in most cases a cash deposit could not be made, and payment had to be made in instalments. ${ }^{7}$ The new private trawling companies had bought most of the STI's vessels and storage facilities, but had refrained from taking over the shops and coastal depots, which generally found other uses. 
By initially focusing on fishing and wholesale and not investing in retail facilities, the trawling companies had avoided some of the costly mistakes of the STI. By mid 1920's the private trawling industry had consolidated itself into three companies, which controlled steam trawling in NSW and until the 1950s were able to dominant the market for sea-fish (Jacobsen 2010). The three companies were known as Cam and Sons, Red Funnel and A.A. Murrell.

\section{Cam and Sons}

The oldest of the company to dominate the NSW steam trawling industry was Cam and Sons, also early known as Cam Brothers, Mess. Cam and Sons, and later Cam and Sons Ltd. Owned by a family of Italian descendants Charles Caminitti (or Cam) began selling fish from his own shop in 1913 and in 1918 became a wholesale fish-agent at the Commonwealth Co-operation Fish Exchange in Redfern. ${ }^{8}$ By 1920 he had expanded the business further by becoming sole agent of the State Trawling Industry, which by then had closed the wholesale part of its business. ${ }^{9}$ Trading must have been profitable, because in 1923 Charles Cam was able to buy his first trawler from the STI. During the 1920s business was thriving and Cam expanded the trawling business until the fishing fleet consisted of eight vessels by the end of the decade. ${ }^{10}$ Of the eight trawlers, three were built by governments for commercial or defence purposes. In 1934 Cam and Sons consolidated the company by incorporating it under the name Cam and Sons Limited and transferring all assets previously owned by the founder Charles Cam to the new company. All the shares were distributed to family members, and Charles Cam remained in control of the company until his death in 1947, where he was succeed by his son Rocco (Cooke 2006).

\section{Red Funnel Fisheries Limited}

The second largest steam trawl company was Red Funnel Fisheries Ltd. The company was established in December 1925 and consolidated itself by absorbing several smaller companies. During its existence, the company went through several changes of ownership. Red Funnel Fisheries Limited was incorporated on the 2 December 1925 with a capital of $£ 75,000$, taking over two former STI trawlers from Douglas Paul Hann as well as the New State Fish \& Ice Company. ${ }^{11}$ In its setup Red Funnel was ambitious and committed to rapid development. In January 1926 Red Funnel incorporated the business of Carlyon Ltd., which included the former State trawlers Goonambee, and a cool store in Newcastle. ${ }^{12}$ Red Funnel not only expanded by absorbing other companies; in June 1926 Red Funnel also bought the former navy British steam trawler Gunner. To further fuel the compa- 
ny's growth an extraordinary general meeting of shareholders was held in October 1926 , and it was decided to increase the nominal capital by $£ 100,000$, making the total capital $£ 175,000$. According to Red Funnel's second progress report, the company had a profit of $13.3 \%$ in the first ten months and it had increased its profit earning assets $200 \%$. By 1929 the fleet consisted of eight trawlers ${ }^{13}$ all of which had been built for various governments to serve commercial or naval purposes and the company was operating from the former State Trawler Depot at No. 5 Wharf, Woolloomooloo. The growth of Red Funnel continued until 1928/29 when the company, along with the rest of the trawling industry, was hit by falling catches and economic recession. As a consequence the company was reconstructed in 1935 and began operating under the name Red Funnel Trawling. After 1935 only sketchy information about the company's ownership and financial arrangements is available.

\section{A. A. Murrell}

Little is known about the third of the main steam trawling company operating in NSW. The only surviving records from the company are two logbooks kept at the National Archive in Canberra. What is known is that Arthur A. Murrell, a former clerk, began his business as a fish retailer and later became a licensed fish agent and fish merchant. In 1926 Murrell bought his first vessel (Lorimer 1984), the Scottish built trawler David Blake. The David Blake was originally built for the British Admiralty as a minesweeping vessel in 1918, but was decommissioned in 1921 and later sold to A.A. Murrell in 1926. The vessel was typical of the type of trawlers that had been bought in the 1920s by the private steam trawling companies, which favoured second hand steam trawlers of 'Castle' class, built before 1920. A. A. Murrell was successful in his venture; his business setup put him in control of all steps from capture to consumers, and produced an annual turnover of between $£ 70,000$ and $£ 89,000 .{ }^{14}$ In January 1929 he expanded the business further by adding Samuel Benbow to his fleet. Samuel Benbow was sister ship to David Blake, also built to the British Admiralty in Aberdeen. ${ }^{15}$ The last vessel to be acquired by A. A. Murrell in the 1920s was the trawler Tongkol built for the Fisheries Authorities in British Malaya. Unlike the other steam trawling companies, trawl fishing was only a minor part of A. A. Murrell's fish merchant business and catches were mostly traded through his own retail outlets or wholesale customers.

As a consequence of the progress made by the three trawling companies by the end of 1929 the total Sydney based trawling fleet consisted of 18 vessels, seven which had been added during 1929. Most of the trawlers were of Castle class, from 220-278 tons gross register, with crews of 13, who were paid fixed rate wage and catch bonuses. The vessels had cruising speeds of 9 to 11 knots and were equipped with wireless telephone so they could be in contact with their shore offices and the other vessels. Before each voyage the trawlers would load 15 tons of 
ice used to cool the fish in specially insulated chambers. Fishing was done with otter trawl of about 140 feet long with a mesh size of 6 inches in the wings decreasing to $3 \frac{1}{2}$ inch in the cod end (bottom end of the trawl). The upper edge of the net was 90 feet long and the lower 140 feet. The rope at the edges was attached in each side to two 'otter boards' or 'doors' of 10 feet long, 4 feet 6 inches high which purpose was to kept the net open during trawling. Attached to each otter boards was 400 fathoms of wire rope which was wounded up on two drums placed aft pulled by steam winches. As shown on Figure 10.1 gas lamps were placed with regular intervals on the deck so fishing could take place during nigh (Roughley 1916). After 1925 the modified Vigneron-Dahl otter trawl became common. The trawl differenced from earlier models by the way the doors was connected to the net by long bridles, allowing the net to spread wider and increased turbulence in the water to herded more fish into the net. As a consequence fishing efficiency increased by about a third (Klaer 2006).

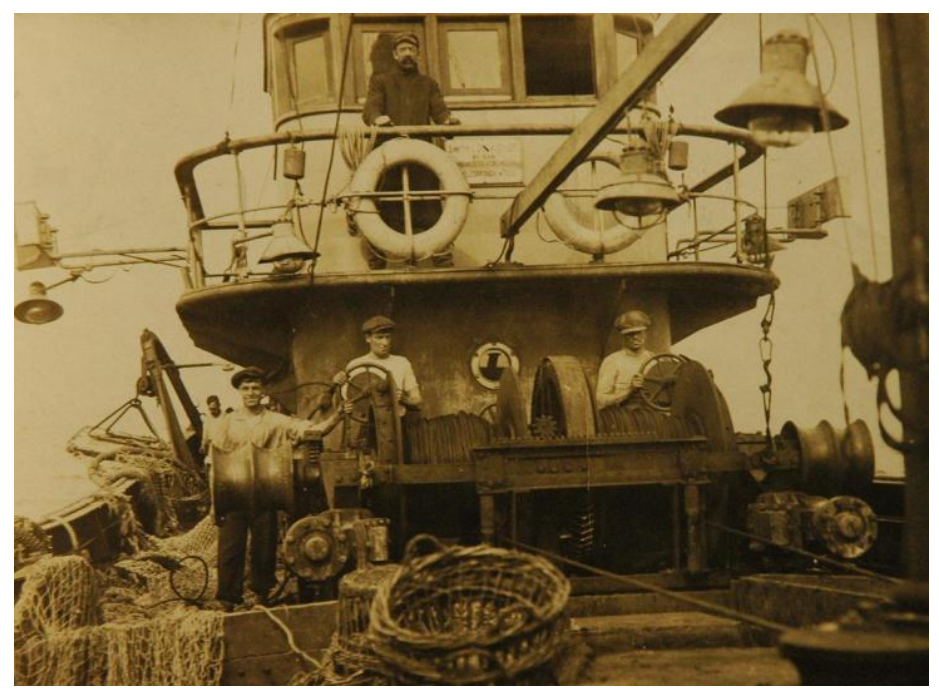

Fig. 10.1 Crew on aft deck with net and stem winches on a State Trawler, 1914-1921. (Source: SLNSW: David G. Stead; [ML MSS 5715 11(25)]).

As shown above, private companies were able to buy the assets of the former STI at much reduced prices, making establishment costs low and affordable for even small scale investors. The private trawling industry benefited from the fact that the NSW Government had introduced trawl fish to the consumers and developed a market that could absorb large landings of sea fish like flathead. The result of this support was that the private industry grew rapidly and expanded to the point where overfishing became possible. In particular, the valuable flathead stocks were beginning to be negatively affected by the fishing pressure, which in the 1930s would throw the private industry into deep crisis. 


\section{Location of trawling grounds}

When trawling began in 1915, the main fishing ground was located close to Sydney, just south-east of Cronulla (called the Botany Ground), but when the initially high catches began to decline the trawlers began to search further away. Within a year the trawlers began to sail as far south as Green Cape to trawl for fish, on ground found between 1-8 miles or about 1.5-13 kilometres off the coast (Roughley 1916). The long distances sailed by the trawlers in the early years can partly be explained by the lack of knowledge about the habits and migration patterns of target species. Although some of the fishing grounds had been mapped by the Endeavour, there was little knowledge of what species the grounds contained, so particularly in the earlier years the trawlers had to undertake a lot of exploration work to identify the best fishing grounds. ${ }^{16}$ As the captains became better at finding the fish, catch per unit of effort (CPUE) rose on the grounds.

Research using trawling logbooks ${ }^{17}$ has showed the gradual expansion of the waters fished by the fleet. During the time of the STI the main fishing ground was primarily found outside Botany Bay on what was called the Home Ground, and secondly in the waters between Eden and Merimbula. A little fishing also took place in waters north of Sydney and around Montagu Island. Nearly all trawling took place more than three nautical miles offshore, beyond the limit of territorial seas, but throughout the existence of the STI the most important fishing grounds were those closest to Sydney. No haul data has survived from the private trawling industry before 1937, so the early movements of the privately owned steamtrawling fleets are not known. From 1937 to 1943 the fishing effort was distributed over most of the fishing grounds, although most effort was expended south off the coast, near Cape Everard. As World War II progressed, the fishing effort decreased south of Eden and intensified in the grounds closer to Sydney. Haul data covering the final years of steam trawling in NSW from 1952 to 1957 shows that the main fishing effort was again concentrated in the most southerly grounds and relatively less fishing took place on the grounds closest to Sydney (Klaer 2001).

The average depth of fishing between 1918 and 1923 during the time of STI was 75-100 metres and the period after 1937 between 110-130 metres, indicating a transition to progressively deeper waters as CPUE declined (Klaer 2001). Given that the continental shelf is quite narrow off NSW (maximum of about $40 \mathrm{~km}$ ) and the continental slope begins at 150-190 metres depth, in the 1930s the private steam trawling industry had expanded the fishing areas to the very edge of the shelf.

The expansion of the fishing areas meant more days at sea. The STI trawlers were usually at sea for three to four days, after which they returned to Sydney with their catches, but by 1930 the length of voyages varied between nine to as much as twenty-five days. ${ }^{18}$ 


\section{Catches and the effect on fish stock}

Fish landings by the NSW steam trawlers from the east continental shelf show a progressive and pronounced increase from 1923 to 1929. In 1929 landings reached an all-time record of 6,665 tons. During the 1930s landings declined steadily, until they suddenly plummeted between 1939 and 1946, when most of the steam trawlers were taken over by the Royal Australian Navy to be used as minesweepers. The post-war period saw a brief return to the pre-war level of landings, but landings soon continued their previous rapid decline, particularly after 1954 when the trawling company Cam and Sons ceased to operate.

Fig. 10.2 also shows the gradual emergence of a non-steam trawling industry, gaining strength from 1936 when Danish seiners were introduced to the fishery. Their number increased after the Second World War, culminating in 1947-48 when 134 licenses were issued (Houston 1955). By the mid 1950s ocean landings from the seining and small vessel fishing industry were greater than landings from the steam trawlers.

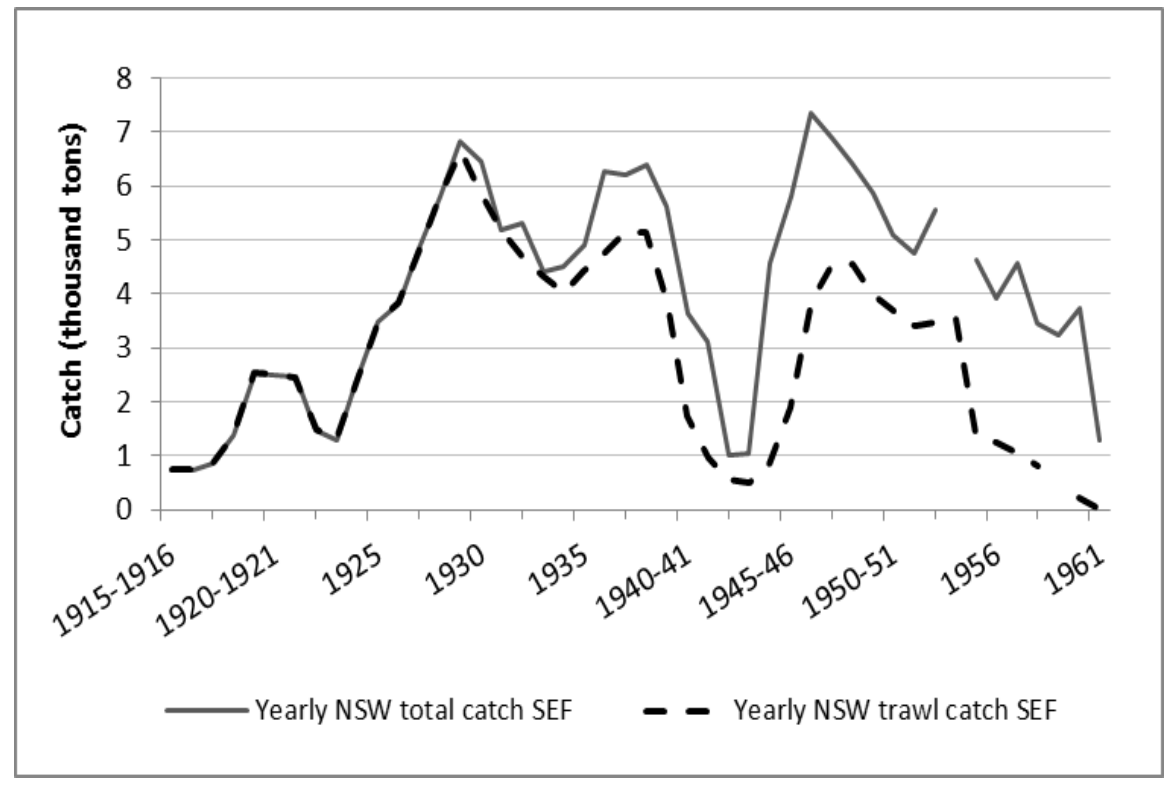

Fig. 10.2 Total catches in tonnes by NSW steam trawlers and other fishing vessels from fishery at the south east continental shelf (SEF) (Source: Klaer, N., 2006).

In 1920 the trawl fishery was well-established and many of the fishing grounds on the continental shelf had been identified and were regularly trawled, affecting fish abundance. As the private industry took over in 1923 and increased the fishing effort, the stocks of the main target catch, flathead but also leatherjacket and 
latchet, began to be affected by the pressure. By the second half of the 1920s the first early signs that trawling was detrimentally affecting and changing the marine environment on the continental shelf can be detected (Klaer 2006). In his research on the historical catch records, Klaer has calculated the CPUE and how the structure of the main demersal fish communities was affected by fishing effort. For the first five years of steam trawling in NSW, CPUE continued to increase, and did not level off before 1920. This suggests that, in the early years of operation, the industry was still developing and not operating with maximum effect. However, over time, an increasing level of knowledge allowed trawlers to improve catch rates. This 'period of learning', as Klaer calls it, continued until about 1920 at which time CPUElevelled off (Klaer 2006). Dealing specifically with the economically important Botany Ground, Klaer's calculations show the same trend of increasing CPUE from 150 to 300 kilograms per hour from 1918 to 1923. After the STI left the fishery and the private industry took over in 1923 CPUE appears to level off, although the lack of data makes it impossible to fix the exact time when CPUE began to fall. However, archival research has shown that by 1928 the valuable flathead fishery on the Botany Ground had collapsed, throwing the trawling companies into crisis (Jacobsen 2010). Similar patterns of briefly increasing and then declining CPUE were found on other major fishing grounds although slightly later than on the ground near Sydney (Klaer 2006).

Without a complete time series of catch data it is impossible to estimate the precise impact of fishing on the marine environment during the second half of the 1920s and first half of the 1930s. Based upon the data available, it is obvious that CPUE dropped dramatically for all the known fishing grounds after 1923, suggesting that the fishing effort increased and/or the fish stocks were reacting negatively to exploitation. By 1937 the average CPUE for the steam trawling fleet was less than $50 \%$ of that achieved in the early 1920s (Klaer 2006). Time series data available for the post-war period show a significant decline in CPUE compared to the earliest data and radical changes in species composition; this finding has been confirmed by Klaer's modelling of fish stocks, which shows a steady decline in flathead, leatherjacket and latchet biomass and abundance indices between 1915 and 1961 (Klaer 2006). His population modelling also indicates a permanent biomass reduction in three out of the four studied fish species. In the case of tiger flathead the population was fished down to a low level of about $20 \%$ of its pre-1915 stock size in the 1950s and 1960s, but has today recovered to its current level of $40 \%$ (Scandol et al. 2008). Klaer judged fishing the most likely cause of the reduction in biomass. From this information it is clear that the steam trawl fishery was unsustainable, and in decline from the late 1920s. 


\section{Decline in landings and economic recession, 1928-1938}

Two events halted the progress of the steam trawling companies by the end of the 1920s; the downturn of the Australian economy during the Great Depression, and the collapse of the valuable flathead fishery at the Botany Ground in 1928.

The 1920s had been characterised by significant public spending on infrastructure funded by overseas borrowing (mainly English capital) to stimulate economic growth. The State Government's investments had heavily favoured activities in urban and metropolitan areas (Butlin et al. 1982). The collapse of the American stock market in 1929 triggered what is known as the Great Depression, a global economic downturn that lasted until the late 1930s. Australia's economy was hard hit by the Depression, because the nation relied on the export of agricultural products. When the prices of wool and wheat fell in early 1929, and exports dropped along with the withdrawal of English capital that had fuelled many of the 1920s public projects, Australians faced a severe financial crisis (Clark 2006). Of all the states NSW was worst hit by the economic downturn. Unemployment in the industrial sector rose to a point where one in three unionists in NSW was unemployed in 1932. The highest rate of unemployment was found in the State's industrial districts and throughout the cities (Kingston 2006). A stagnant economy and reduced economic activity hit the trawling companies hard. With the trawling companies selling their catches nearly exclusively at the Municipal Market they were vulnerable to changes in urban demand for their product. Due to its relatively high price fish was often considered a luxury food item for the average household and only when landings were abundant, and prices were lower than normal, could fish be considered a basic staple on a par with meat. ${ }^{19}$ Falling demand, low prices and increased costs strained the finances of the companies, a situation that lasted for most of the 1930s. Furthermore, the flathead fishery at the Botany Ground collapsed during the season 1927/28 and overall catches started to decline. Between 1928 and 1932 catches declined by 30\% (Jacobsen 2010). The Fisheries Department estimated that trawl landings in general had declined from an average of 400 boxes (12.7 tons) of fish per vessel per week in 1926 to 360 boxes (11.4 tons) in 1927 , to only 270 boxes ( 8.6 tons) of fish per week in $1928 .^{20}$

Decreasing productivity had a serious effect on the financial situation of the companies. Estimates prepared by Colin W. Mulvey, in February 1928 for the Australian Fisheries Conference, calculated costs and earnings of a trawler engaged in the Sydney trawl fishery in 1927 and 1928. Based upon an average catch in 1926 of 400 boxes per week sold at 21 shillings, total costs including commissions and fees (organisation expenses not included) amounted to $£ 16,070$ making a profit of $£ 4,930$ before taxes per year per vessel. Because those vessels built in NSW were about 50\% more costly in insurance and depreciation than their British counterparts, and generally more expensive to run, they only earned a profit of $£ 3,760$ before tax. ${ }^{21}$ Using Mulvey’s information about costs and earnings, it is possible to roughly estimate the economic impact of reduced landings. If landings 
in 1928 dropped to 270 boxes per week per vessel and were sold for the same price ( 21 shillings), the total cost per vessel would be $£ 14,800$ but the profit would instead turn to an annual loss of $£ 623$, and even more for the trawlers built in NSW.

As the Botany Grounds yielded less fish, fishing efforts on the more distant grounds intensified, raising production costs. In addition the companies had continued to invest in second-hand trawlers to keep up production (the trawling fleet increased from 11 to 18 vessels in 1929) which had to be paid off. The economic downturn beginning in 1929 would also have contributed to reduced earnings. Based upon the above estimates, there is no doubt that from about 1928 the industry experienced growth in operational costs and decline in earnings causing significant financial stress, especially when the catch from the Botany Ground did not recover. The collapse of this important, near-city fishing ground was symptomatic of a general depletion of the NSW trawling grounds.

When the catch declined continued in the 1930s (see Figure 10.2) the trawl companies tried several strategies to improve their financial situation. Several times they used their market dominance to improve wholesale prices by withholding landings from the market by laying up vessels. ${ }^{22}$ Also there were attempts to land in Melbourne to build up a market for trawled fish there, but the venture was discontinued (Jacobsen 2010). To increase catches and make their trawlers pay both Red Funnel and Cam and Sons turned their attention to trawling grounds in New Zealand waters. From 1934 Cam trawlers were regularly fishing New Zealand grounds, landing their catch in Sydney (Johnson 2004). In 1938 they were joined by a trawler from Red Funnel. Trawling in New Zealand waters was not the only alternative fishing strategy Red Funnel explored in the 1920s. Danish seine boats, had been introduced into the shelf fishery in 1936, and by 1937 Red Funnel had acquired its own large seiner which it operated until the war. Being the most versatile of the three trawling companies Cam and Sons also turned to coal mining during the 1930s to reduce costs, since coal was the source of fuel used to power the trawlers' steam engine and made up a large part of the trawlers' working expenses (Cooke 2006).

\section{The trawling companies' situation by 1939}

By 1939 all the known trawling grounds on the Australian South East continental shelf were fully exploited, and the trawlers had increased their trawling depth and extended the fishery to the edge of the shelf. The companies' situation had improved somewhat as the Depression eased off, but the general economic outlook for the industry was still not promising.

Cam's venture into trawling in New Zealand and branching out to coal had given Cam a competitive edge over the other trawl owners and allowed the com- 
pany to remain viable. However the company was left with a reduced and aging fleet compared to its situation in 1929.

Red Funnel Fisheries had also recovered somewhat from economic hardship and the decline in landings caused by overfishing of the continental shelf. After 1929 its shares had plummeted and by 1933 the company sold of some of its trawlers and was reconstituted into a new enterprise. This gave the company some much needed economic stability.

While the other two trawling companies had extended their operations to include other types of gear or fishing grounds, A. A. Murrell had continued to rely exclusively on fishing with steam trawlers on the continental shelf, supplying primarily its own shops and wholesale business. By the end of 1939 Murrell had virtually left the fishing industry, having sold all of his trawlers, and relied on its fish merchant business.

\section{Second World War, 1939-1945}

The outbreak of the Second World War radically changed the situation of the trawling companies, and brought them out of the economic deadlock they were in. The Royal Australian Navy (RAN) needed fishing trawlers for minesweeping in Australian waters and had to rely on the private companies to supply them. Between September 1939 and June 1942 the RAN requisitioned 12 out of 14 trawlers leaving only Bareamull from Red Funnel and Dur-een-bee from Cam and Sons to supply the market. The situation was initially not without appeal to the trawl owners. The Navy's requisitions reduced the companies' burden of maintaining and running aging vessels and the charter hire paid by the Navy provided the companies with a stable source of income, instead of having to rely on the return from fishing the declining resources on the continental shelf.

Steam trawlers were an essential part of Australia's naval defence and the owners, controlling the only fleet of large trawlers in Australia, used the situation to their advantage. First they pressed for a significantly higher rate than the one proposed by the RAN, which was based upon rates given by the British Admiralty, but with only limited success. ${ }^{23}$ Later in 1941 the trawl owners suggested that the Navy buy the vessels outright instead of hiring them; they assured the Navy that all the trawl owners were prepared to repurchase the vessels after the war. ${ }^{24}$ From June 1943 the RAN began to buy all the requisitioned trawlers. As the value of fishing vessels had increased dramatically since the outbreak of the war, the trawling companies gained a considerable profit they could use to reinvest in newer trawlers after the war.

Just how significant the profit was can be illustrated by the sale of Cam and Sons trawlers. In June 1943 the RAN purchased all six steam trawlers ${ }^{25}$ requisitioned from Cam and Sons for a total sum of $£ 65,000$. All of Cam's trawlers were between 23 and 30 years old at the time of purchase. In 1934 five Cam trawlers, 
which were of similar type and age to the ones purchased by the RAN, had been valued at $£ 12,500$ total. Even if the Cam trawlers' value in 1934 might then have been estimated below market prices for taxation purposes, the rise in value between 1934 and 1943 was impressive. Given that the trawlers were old and poorly maintained at the outbreak of the war Cam made a generous return on their initial investment.

\section{Fishing During the Second World War and the Immediate Post- War Era}

As the war continued the RAN requisitioned more steam trawlers along with most of the independently owned seiners, and fish landings dropped dramatically while market prices rose. The fishing effort was severely affected, as by 1943 the fishing fleet was down to one steam trawler Red Funnel's Bareamull, which the Navy due to the deteriorated state of the wooden hull, had decided was unfit for service. Consequently the annual steam trawl landing was as low as 1,032 tons, but on the other hand prices had more than doubled compared to pre-war levels (Klaer 2006). Although lacking a fishing fleet the other companies did not totally miss out on the favourable market conditions, as they instead increased their agent activities and began selling fish from the inshore fishing industry. In second half of 1944 the RAN also released a trawler to each of the three trawling companies, to increase productivity.

After the war the conversion of the trawlers back to fishing vessels and their return to the owners was slow due to a labour shortage, congestion of dry docks and slipways, and industrial trouble. Most of the seven remaining trawlers were not returned before the second half of 1946. When the trawlers were surveyed before being refitted, it was discovered that many were in great need of repair. In the case of Red Funnels Goolgwai and Durraween, Lloyd's surveyor in May 1946 found that the all of the steel decking, and a large part of the superstructure and engine room casing had to be replaced for the vessels to be in class. The officer in charge assessed that the cost of the repairs and necessary reconversion amounted to about $£ 22,000$ for Goolgwai and £20,000 for Durraween. Despite the damage being due to normal wear and tear mostly sustained before the RAN took over the ships, the Navy had very little luck with getting Red Funnel to share the costs. ${ }^{26}$ In July 1946 Red Funnel successfully argued that the charter rate had been too low compared to what the company could have earned if the trawlers had been engaged in fishing during the time the vessels were charted, and since the trawlers had been in class when they were taken over by the navy it was the RAN's responsibility to bring them up to standard. In the end the Navy bore the brunt of the costs, acknowledging that they returned the vessels: 'in a condition vastly superior to that in which they were taken from the owners'. ${ }^{27}$ Although all three major trawling companies complained that they had lost money by chartering their ves- 
sels to the Navy rather than using them for fishing, there is no doubt that the companies ultimately benefited financially from the war.

With a newly reconditioned fleet, high wholesale prices, a comfortable net worth and relatively high catch rates, the trawling companies were ready to renew their interests in steam trawling. Accordingly both Red Funnel and A. A. Murrell invested in newer trawlers from New Zealand. Red Funnel, which had lost one of its trawlers during the war, bought in 1946 three newly built, former Royal New Zealand Navy minesweepers, of a similar design to those already fishing from Sydney, for less than a fourth of the original delivery price. ${ }^{28}$ A. A. Murrell bought the two sister vessels under similar conditions the same year (Waters 1956). The very reasonable price for ex-navy vessels allowed the companies to invest in several trawlers at the same time, instead of having to expand their fleet more gradually. It also boosted the activity of the trawling companies in similar ways to that which occurred after the sale of the state trawlers in 1923.

\section{Changes in Species Composition}

Despite the capital injection and rejuvenation of the fleet that had taken place after the war, the optimism was short-lived and during the 1950s and early 1960s the economics of the trawling industry deteriorated further. The reason for the collapse was found in the changes in catch composition caused by over-fishing and the subsequent fall in earnings.

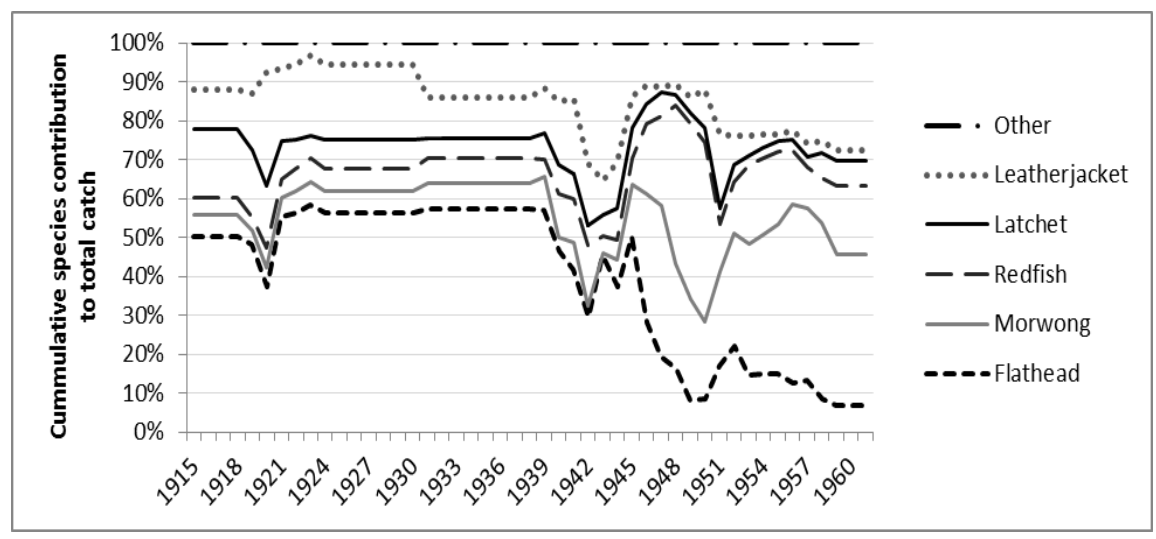

Fig. 10.3 Catch proportions by species for steam trawlers, 1915-1961 (Source: Klaer, N., 2006).

Throughout its history the NSW steam trawling industry targeted several species, but flathead was the main target species and the most valuable in terms of price per kilogram. Klaer's estimate of the changes in the species composition of the catch reveals that after 1939 there was a clear trend towards decline in catches 
of flathead and an increase in catches of less valuable species such as morwong and redfish (Figure 10.3).

Until 1939, flathead comprised about half the catch of the steam trawlers, but after 1939 the proportion declined rapidly until flathead made up only $6.8 \%$ of the catch in 1961. Leatherjacket and latchet followed a similar trend, their proportion of the catch being reduced slowly since 1930 and nearly disappearing in the postwar period, although latchet in the final years increased to post-war levels. Catches of morwong and redfish increased dramatically, especially in the post-war period. In 1915 morwong only made up $5.6 \%$ of the catch but in 1961 it accounted for as much as $38.7 \%$ of all catches. The increase in redfish was more modest, from $4.5 \%$ in 1915 to $17.9 \%$ in 1961 . By the end of the period 'other species' made up nearly one third of landings. Changes in species composition were most likely due to the impact of previous decade's unrestricted exploitation of the continental shelf.

\section{Fish Prices and Earnings}

The changes in species composition documented after 1939 had a profound impact on the earnings of the trawling companies. Recordings of monthly and annual prices received for fish by Red Funnel Trawlers is available from 1939 to 1952 (Klaer 2006). The data can be used to estimate a pattern for value of fish in NSW during the period, as well indicate overall trends in trawling companies' earnings.

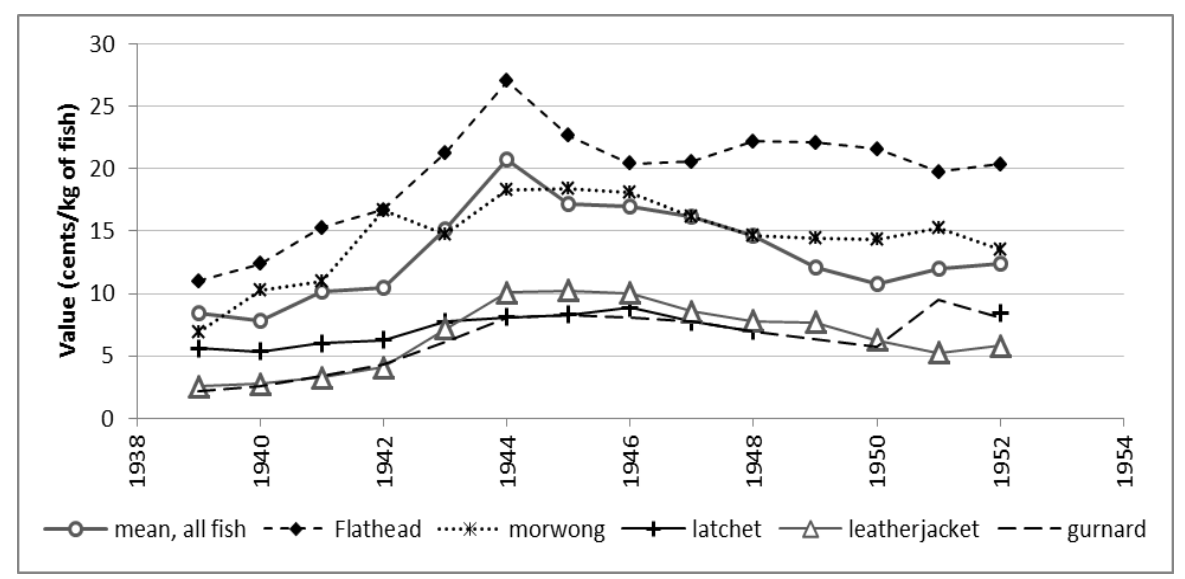

Fig. 10.4 Average price received by Red Funnel of main species per financial year, 1939 -1952 Converted by Klaer to cents per kilogram. (Source: Klaer, N., 2006).

Figure 10.4 clearly shows a significant increase in prices from 1941 and a gradual fall during the post-war period, but by 1952 prices were still higher than 
before the war. A system of fixed prices for fish had been introduced during the war, ${ }^{29}$ to avoid overpricing and black marketing. Still the prices received by Red Funnel during the war and in the immediate post war period were significantly higher than peace-time prices. However, the changes in species composition reduced the financial benefit of the high prices. Despite the fact that landings increased until 1948/49 (Figure 10.2) because of increased fishing effort, the overall value of landings began to decrease, due to the changes in species composition.

$\begin{array}{ccccccc}\text { Cents/kg* } & \text { Flathead } & \text { Gurnard } & \text { Latchet } & \text { Leatherjacket } & \text { Morwong } & \text { mean, all fish } \\ & & & & & & \\ 1939 & 10,99 & 2,17 & 5,60 & 2,56 & 6,91 & 8,44 \\ 1940 & 12,39 & 2,56 & 5,35 & 2,75 & 10,28 & 7,87 \\ 1941 & 15,26 & 3,39 & 5,99 & 3,26 & 10,98 & 10,16 \\ 1942 & 16,71 & 4,30 & 6,25 & 4,06 & 16,71 & 10,49 \\ 1943 & 21,29 & 6,15 & 7,77 & 7,20 & 14,76 & 15,13 \\ 1944 & 27,01 & 8,07 & 8,08 & 10,09 & 18,31 & 20,71 \\ 1945 & 22,64 & 8,31 & 8,30 & 10,24 & 18,42 & 17,19 \\ 1946 & 20,40 & 8,05 & 8,84 & 10,06 & 18,07 & 17,01 \\ 1947 & 20,56 & 7,72 & 7,73 & 8,58 & 16,18 & 16,18 \\ 1948 & 22,21 & 6,99 & 7,00 & 7,78 & 14,66 & 14,66 \\ 1949 & 22,11 & 6,39 & & 7,70 & 14,39 & 12,13 \\ 1950 & 21,60 & 5,78 & & 6,26 & 14,32 & 10,74 \\ 1951 & 19,74 & 9,50 & & 5,25 & 15,22 & 11,97 \\ 1952 & 20,37 & 8,09 & 8,43 & 5,80 & 13,54 & 12,45 \\ * \text { Index } 100=1945 & & & & & & \end{array}$

Table. 10.1 Annual earning per steam trawler, based upon total landings and prices received by Red Funnel Fisheries, 1939-1952. Source: Klaer, N., 2006.

The trend in diminishing value of the catch, become even clearer when allowance is made for the number of trawlers involved in the industry. There was a dramatic increase in earnings per vessels from 1941 to 1944, but thereafter earnings per vessel began steadily to decrease (Table 10.1). By 1949 earnings per vessel were lower than in 1939. It was the valuable flathead catch that kept the total earning per steam trawler up. In 1939 flathead comprised 57\% of total catch in weight by the NSW fleet, but $74 \%$ of the total value of annually landings, calculated from the prices recorded by Red Funnel. By 1952 flathead comprised only 
$22 \%$ of the catch, but totalled $36 \%$ of the value of annual landings. As the downward trend in flathead catches continued after 1952 so did earnings per vessel, throwing the companies into a rapid economic decline.

The experience of post-war decline was not unique to the NSW steam trawl industry. Similar experiences were had in the British near- and middle-water fishery, where many of the fishing vessels were steam trawlers. After being released from naval service British trawlers were experiencing high catches because the stocks had enjoyed a respite from fishing during the war, but catches began to decline again around 1946. At the time fish prices were high because of food shortages, but in November 1949 prices collapsed after the Government removed price controls. Because of the combination of declining catches caused by long-term overfishing and low post-war prices, the rate of vessel replacement was slow (Starkey et al. 2000). By 1952, 78\% of the British near- and middle-water fleet were built before 1921 - the figure for the NSW steam trawling industry was very similar at $77 \%$.

By the early 1950s only Cam and Sons and Red Funnel remained in business, after A. A. Murrell had sold off its three trawlers around 1947. Cam was fishing with five trawlers ${ }^{30}$ and Red Funnel with seven trawlers. ${ }^{31}$ In September 1950 the Secretary of Red Funnel, Gordon Francis Thomson and the Managing Director of Cam and Sons, Rocco Edmund Cam testified to an Industrial Commission that both companies had sustained substantial losses during the last two years. ${ }^{32}$ In October 1954 Cam and Sons announced that they were discontinuing business. ${ }^{33}$ Two of its former trawlers were taken over by family members, ${ }^{34}$ who for some years continued to operate the trawlers as individual owners, but in 1965 the trawlers were finally scrapped after having been laid up for years (Cooke 2006).

Due to financial difficulties, Red Funnel was also gradually forced to lay up its fleet, with the last trawlers ceasing fishing in 1958. The reason why Red Funnel was able to continue longer than Cam and Sons was likely due to the fact that the four active trawlers had an average age of about 11 years in 1955, while Cam's vessels were much older. Another reason for Cam and Sons decision to wind up its operations was probably the fact that the shareholding members of the Cam family were near retirement age. In July 1959 Captain Products Ltd of Sydney, ${ }^{35}$ which was a producer and distributor of canned fish products, acquired shares in Red Funnel Trawlers and set out to resume the fishery operating from No 5 Wharf at Woolloomooloo. ${ }^{36}$ In February 1960, after an extensive overhaul the fishing was resumed by one trawler (Roughley 1961). The plan was to gradually expand the activities to include all the trawlers, but it never happened and by 1961 the company had withdrawn its trawler and the NSW steam trawling industry was no more. ${ }^{37}$ While the activities of the trawlers had been particularly destructive to the large fish inhabiting the ecosystem, the closure of the industry did not end the exploitation of marine resources; instead new industries emerged. New technologies enabled smaller boats to continue the fishery on previously inaccessible grounds, and fisheries for unexploited species and on deeper groundswere developed with the aid of the Commonwealth Government. 


\section{Conclusion}

Steam trawling in NSW has a unique history because it was first promoted by the State before it became a fishery operated by private companies. Whilst the NSW Government's attempt to run a commercial steam trawling industry during 1915-1923 was an economic failure, it did succeed in proving it was possible to catch large quantities of fish on the continental shelf, and to establish a market for these fish in Sydney. Thus failed state entrepreneurship or 'colonial socialism' helped paved the way for private success.

The success of the private steam trawling industry was based upon access to affordable equipment, resources and capabilities left over from the NSW Government State Trawling Industry as well as easy access to reasonably productive fishing grounds. The 1920s was the golden era of steam trawling and the size of the fleet increased significantly during this time. The decline of the industry began around 1928 when the fishery at the Botany Ground collapsed and catches stated to fall. The economic problems were later aggravated when the depression reduced consumer demand and increased costs. The general reduction and ageing of the trawling fleet by 1939 illustrate the financial stress the companies were under during the 1930s.

The companies' financial circumstances improved during the Second World War when the Royal Australian Navy leased or bought most of the trawlers for minesweeping at very profitable rates. At the end of the Second World War the industry had somewhat recovered from the long decline during the 1930s. The recovery was not achieved because of a wiser use of marine resources, but was caused by improved market conditions which continued into the post war period. The final collapse of the private trawling industry over the period from 1954 to 1961 was caused by the combination of overcapacity in the trawling fleet, the return to a free-market price system in December 1951, combined with long-term decline in landings of the most valuable species (flathead). Together these three factors undermined the economy of the industry which resulted in the demise of the steam trawl industry in NSW.

The era of steam trawling also had a long lasting effect on the marine environment. Klaer's modelling of fish stocks shows a steady decline in flathead, leatherjacket and latchet biomass and abundance indices since 1915 (Klaer 2006) His population modelling indicates a long-term biomass reduction in three out of the four studied fish species. In the case of tiger flathead the population was fished down to a low level of about $20 \%$ of its pre- 1915 stock size by the 1950 s, but has today recovered to its current level of $40 \%$. The recovery is due to the introduction of mesh size regulations following extensive biological research and some reduction in fishing effort (Scandol et al. 2008). 


\section{Acknowledgments}

The author wishes to thanks the participants at the HMAP-Asia workshop 2009, under the auspice of the Census of Marine life. Credit for funding my research goes to school of Geography and Environment, University of Tasmania. I am very grateful to Malcolm Tull and Joseph Christensen, Murdoch University, for valuable comments and help with the manuscript and to Kevin Rowling, Cronulla Fisheries Centre, DPI NSW, for his observations on fisheries research. Thanks also go to the following people for their advice and assistance: Elaine Stratford, University of Tasmania, Neil Klaer, CSIRO, René Taudal Poulsen, Copenhagen Business School, and Bo Poulsen, Aalborg University.

\section{References}

Butlin NG, Barnard A, Pincus JJ (1982) Government and Capitalism. Public and Private Choice in Twentieth Century Australia. George Allen \& Unwin, Sydney

Clark M (2006 [1963]) A Short History of Australia, 4th rev. Penguin Books, Ringwood

Cooke S (2006) Oceans, Rivers and Dreams. The Story of the Cams and Cam \& Sons. Stuart Cooke, Sydney

Houston TW (1955) The New South Wales Trawl Fishery: Review of Past Course and Examination of Present Condition. Australian Journal of Marine and Fresh Water Research 6 (2) (2):164-208

Jacobsen ALL (2010) Steam trawling on the south-east continental shelf of Australia. An environmental history of fishing, management and science in NSW, 1862-1961. University of Tasmania, Hobart

Johnson D (2004) Hooked: The Story of the New Zealand Fishing Industry [Edited and completed by Haworth J]. Hazard Press Limited for the Fishing Industry Association, Christchurch

Kingston B (2006) A History of New South Wales. University of New South Wales, Sydney

Klaer NL (2001) Steam Trawl Catches from South-Eastern Australia from 1918 to 1957 : Trends in Catch Rates and Species Composition. Marine and freshwater research 52:399-410

Klaer NL (2006) Changes in the Structure of Demersal Fish Communities of the South East Australian Continental Shelf from 1915 to 1961 . University of Canberra,

Lorimer M (1984) The Technology and Practices of the New South Wales Fishing Industry 1850 - 1930. University of Sydney,

Roughley TC (1916) Fishes of Australia and Their Technology. Technical Education Series No. 21, R. T. Bake edn. Technological Museum Sydney, Sydney

Roughley TC (1961) Fish and Fisheries of Australia. 4 ed. Angus \& Robertson, Sydney

Scandol J, Rowling K, Graham K (2008) Status of Fisheries Resources in NSW 2006/07. vol 334. NSW Department of Primary Industries, Cronulla

Starkey DJ, Reid C, Ashcroft N (eds) (2000) England's Sea Fisheries. The Commercial Sea Fisheries of England and Wales since C.1300. Chatham Press, London

Tyler PJ (2006) Humble and Obedient Servants, vol 2: 1901-1960. The Administration of New South Wales, UNSW Press, Sydney

Waters SD (1956) The Minesweeping Flotillas. In: The Royal New Zealand Navy. Historical Publications Branch, Wellington, pp 266-278 
The Wealth and Progress of New South Wales (1887-1902). Government Statistician's Office, New South Wales, Sydney

\footnotetext{
${ }^{1}$ The value is based on NSW catch statistics for 2006/2007 by NSW Primary Industries, Fisheries and Aquaculture. www.dpi.nsw.gov.au/fisheries/commercial/catch-statistics\#NSW-reportedcommercial-wild-harvest-for-2006-2007-by-fishery-including-gross-weight-\% $\% 28$ tonnes $\% 29$-andestimated-value- $\% 28 \$ 27000 \% 29$ [01.04.2011]

${ }^{2}$ The Argus, 14 April 1923, p. 6.

${ }^{3}$ A complete list of all NSW based steam trawlers participating in the south-east trawl fishery can be found in Jacobsen, 2010, Appendix 2.

${ }^{4}$ Within 10 months of buying its first trawler, the company had paid off the trawler and was looking to expand its business. Over the next two years the company bought another former STI trawler and attempted to build a market for trawled fish in Melbourne, Victoria. On 22 October 1926 Coastal Trawling Company amalgamated with Red Funnel Fisheries Ltd.

${ }^{5}$ The original price of SS Koraaga from Smith's Dock Middleborough-in Tees, UK was $£ 7,500$. Additional costs of outfitting and delivering in Sydney amounted to $£ 5,000$. Sold in 1923 for $£ 8,000$.

${ }^{6}$ The Argus, 22. December 1924, p. 17.

${ }^{7}$ Lif Jacobsen Private Collection: Chief Secretary's Department: F. J. Herlihy: NSW State Trawling Industry Historical Records 1915-1923, September 1927, p. 36.

${ }^{8}$ State Records of New South Wales: State Fisheries; Letter, 22 February 1922 [4/6636.2].

${ }^{9}$ State Records of New South Wales: State Trawling Industry; Papers relating to the 1920 inquiry into the State trawling Industry [5/5366].

${ }^{10}$ SS Goorangai (1923) SS Charlie Cam (1925), SS Beryl II (1926), SS Camro (1927), SS Oliver Cam (1928), SS Alfie Cam (around 1929) and SS Mary Cam (around 1929).

${ }^{11}$ State Records of New South Wales: Item 9920; Red Funnel Fisheries Limited, Memorandum and Article of Association of the Red Funnel Fisheries Limited, 2 December 1925, [17/5605].

${ }^{12}$ State Records of New South Wales: Item 9922, Red Funnel Fisheries Limited, Memorandum of satisfaction of mortgage of change July 1926 [17/5605].

${ }^{13}$ SS Bar-ea-mul (1925), SS Dureenbee (1925), SS Goonambee (1926), SS Gunundaal (1926), SS Koraaga (1926), SS Millimumul (1926), SS Durraween (1928), SS Goolgawai (1928).

${ }^{14}$ Sydney Morning Herald: Trawling Fleet, 1 February 1929, p. 13.

${ }^{15}$ www.aberdeenships.com [10.03.2010].

${ }^{16}$ State Records of New South Wales: Public Service Board: Inquiry in the State Trawling Industry, 1916-1917; Statement of Captain Charles Horn, 14 June 1916 [8/513.3].

${ }^{17}$ As part of the HMAP-South East Australia a comprehensive study of data extracted from historic trawling logbooks have been done Neil Klaer to estimate absolute biomass trends. See Klaer, N., 2006.

${ }^{18}$ Commission of Taxation v. Cam and Sons, 1936.

${ }^{19}$ Annual Report on the Fisheries of NSW for the Year 1929, p.2.

${ }^{20}$ Annual Report on the Fisheries of NSW for the Year 1929, p. 4.

${ }^{21}$ Lif Jacobsen Private Collection: Letter from Colin W. Mulvey to S. Fowler, Secretary to the Australian Fisheries Conference, 28February 1928.

${ }^{22}$ Annual Report on the Fisheries of NSW for the Year 1929, p. 2.

${ }^{23}$ NAA: Navy Office [MP150/1/0 674/201/3230].

${ }^{24}$ NAA: Navy Office [MP150/1/0 674/203/442].

${ }^{25}$ SS Alfie Cam, SS Beryl II, SS Goonambie, SS Mary Cam, SS Oliver Cam and SS Samuel Benbow

${ }^{26}$ National Archive of Australia: Navy Office [674/201/3230].
} 


\footnotetext{
${ }^{27}$ National Archive of Australia: Navy Office; The Deputy Superintendent to the Department of the Navy, 10 May 1946 [674/201/3230].

${ }^{28}$ A forth conventional trawler SS Mulloka was bought by Red Funnel around the same time.

${ }^{29}$ In December 1951 fish was removed from price control.

${ }^{30}$ SS Alfie Cam (built 1920), SS Beryl (built 1914), SS Goonambee (built 1917) SS Mary Cam (built 1918) SS Olive Cam (built 1920)

${ }^{31}$ SS Durraween (built 1918), SS Goolgwai (built 1918), SS Korowa (built 1919), SS Maldaana (built 1942), SS Matong (built 1944), SS Moona (built 1943), SS Mulloka might not have been added to the fleet before 1955. SS Bar-ea-mul was scuttled in December 1950 after having been laid up for several years.

${ }^{32}$ Sydney Morning Herald: Trawlers' Losses. 12 September 1950, p. 10.

${ }^{33}$ Fisheries Newsletter, November 1954, vol. 13 n. 11, p. 21.

${ }^{34}$ Fisheries Newsletter, January 1955, vol. 14 n. 1, p. 15.

${ }^{35}$ Former Downs Holdings Ltd.

${ }^{36}$ Fisheries Newsletter, July 1959, vol 18 no 7, p. 9.

${ }^{37}$ Red Funnel Trawlers Ltd continued to hold the lease to the premises on No 5 Wharf until the 1980s where the buildings were demolished as part of the Woolloomooloo harbour-front development. The company still exists but has ceased trading.
} 